\title{
The role of intestinal barrier function and the state of the intestinal microbiome in psoriasis
}

\author{
Togzhan Algazina ${ }^{1}$, Bakytgul Yermekbayeva ${ }^{2}$, Almagul Kushugulova ${ }^{3}$, Samat Kozhakhmetov ${ }^{3}$, \\ Zulfiya Jetpisbayeva ${ }^{1}$, Gulnar Batpenova ${ }^{1}$
}

\begin{abstract}
${ }^{1}$ Dermatovenereology Department, Astana Medical University, Nur-Sultan city, Republic of Kazakhstan ${ }^{2}$ Department of Science and Education, University Medical Center Corporate Fund, Nur-Sultan, Republic of Kazakhstan

${ }^{3}$ Center of Life Sciences, National Laboratory Astana, Nazarbayev University, Nur-Sultan, Republic of Kazakhstan
\end{abstract}

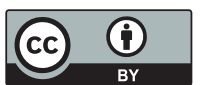

This work is licensed under a Creative Commons Attribution 4.0 International License

Received: 2019-04-24

Accepted: 2019-05-20

UDC: 616.1

J Clin Med Kaz 2019; 2(52):10-15

Corresponding Author: Togzhan Algazina, Dermatovenereology Department, Astana Medical University. Address: 49A, Beibitshilik Street, NurSultan city, Republic of Kazakhstan.

Tel.: 87783441159. E-mail:algazina.t@gmail.com

\section{Abstract}

The literature review summarizes the most recent and basic data on the state of the intestines and the features of the microbiome in psoriasis, as well as on the role of the immune system in this pathology. In patients with psoriasis, various microbial composition of the intestine was often identified, in particular, the main bacterial types of the genus Firmicutes, Bacteroidetes and Akkermansia.

Key words: intestinal microbiome, psoriasis, bacteria

\section{ПСОРИАЗ КЕЗІНДЕГІ ІШЕКТІН ТОСҚАУЫЛДЫҚ ФУНКЦИЯСЫНЫН РӨЛІ ЖӘНЕ ІШЕК МИКРОБИОМЫНЫНЖАЙ-} КҮЙІ

Алгазина Т.О. ${ }^{1}$ Ермекбаева Б.А. ${ }^{2}$, Кушугулова А.Р. ${ }^{3}$, Кожахметов С.С. ${ }^{3}$, Джетписбаева 3.С. ${ }^{1}$, Батпенова Г.Р. ${ }^{1}$

'Дерматовенерология бөлімшесі, Астана Медициналық Университеті, Нұр-Сұлтан қаласы, Қазақстан Республикасы

${ }^{2}$ Ғылым және білім бөлімшесі, Университеттік медицина орталығы корпоративтік қоры, Нұр-Сұлтан қаласы, Қазақстан Республикасы

${ }^{3}$ Өмір туралы ғылым орталығы, Астана ұлттық зертханасы, Назарбаев Универститеті, Нұр-Сұлтан қаласы, Қазақстан Республикасы

\section{ТҰЖЫРЫМДАМА}

Әдебиеттерге шолуда псориаз кезіндегі ішектің жай-күйіне және микробиомның ерекшеліктеріне қатысты, сондай-ақ осы патологиядағы иммундық жүйенің рөлі туралы ең соңғы және негізгі деректер жалпыланған. Псориазбен ауырған пациенттердің ішегінде түрлі микробтық құрам болғаны анықталды, атап айтқанда негізгі бактериялық типтер Firmicutes, Bacteroidetes және Akkermansia тектес бактериялар.

Негізгі сөздер: ішек микробиомы, псориаз, бактериялар

РОЛЬ БАРЬЕРНОЙ ФУНКЦИИ КИШЕЧНИКА И СОСТОЯНИЕ МИКРОБИОМА КИШЕЧНИКА ПРИ ПСОРИАЗЕ Алгазина Т.О. ${ }^{1}$, Ермекбаева Б.А. ${ }^{2}$, Кушугулова А.Р. ${ }^{3}$, Кожахметов С.С. ${ }^{3}$, Джетписбаева 3.С. ${ }^{1}$, Батпенова Г.Р. ${ }^{1}$ ${ }^{1}$ Кафедра дерматовенерологии, Медицинский Университет Астана, город Нур-Султан, Республика Казахстан

${ }^{2}$ Департамент науки и образования, Корпоративный фонд Университетский Центр Медицины, город Нур-Султан, Республика Казахстан

${ }^{3}$ Центр наук о жизни, Национальная Лаборатория Астана, Назарбаев Универститет, город Нур-Султан, Республика Казахстан

\section{РЕЗЮМЕ}

В обзоре литературы обобщены самые последние и основные данные, касающиеся состояния кишечника и особенностей микробиомы при псориазе, а также о роли иммунной системы при данной патологии. У пациентов с псориазом часто идентифицировался различный микробный состав кишечника, в частности, основные бактериальные типы рода Firmicutes, Bacteroidetes и Akkermansia.

Ключевые слова: микробиом кишечника, псориаз, бактерии 


\section{Өзектілігі}

Псориаз қазіргі кезеңде көп таралған созылмалы дерматоздардың бірі болып қалып отыр және қазіргі дерматологияның өзекті проблемаларының арасында жетекшірөлдіалыпотыр.Псориазжөніндегіқауымдастықтың Халықаралық федерациясының (International Federation of Psoriasis Associations) мәліметтеріне сәйкес аталған дерматоздың таралуы жалпы популяцияда 1,2-ден 5\%ға дейін ауытқиды, орташа есеппен 3\%, ал Қазақстанда псориаздың таралуы 2,5\% [1,2].

Псориаз әртүрлі ағзалар мен жүйелерде - тірекқимыл, асқорыту, нерв, жүрек-қантамыр, эндокриндік, репродукциялық жүйелерде өзгерістермен қоса жүруі мүмкін. Жинақталған мәліметтер бұл ауруды терідегі белгілермен басым көрінетін жүйелі «псориаздық ауру» ретінде қарастыруға мүмкіндік береді [3].

Осы ауруды тиімді емдеу үшін этиопатогенездік емін нақты анықтау қажет, бұл қазіргі күні мәселенің осы жағы аз зерттелгендіктен мүмкін болмай тұр.

Соңғы жылдары синатроптық микрофлораның өзгеруі аурудың басталужәне созылмалықабынбаны қолдау факторы деген теорияны дәлелдейтін жаңа дәлелдер пайда болды [4,5]. Микрофлораның сапалық құрамы адамның жасына, оның генетикалық ерекшеліктеріне, тұратын жеріне, түрлі дәрілердің ықпалына тығыз байланысты екенін атап өткен жөн. Ересек адамда егер саламатты өмір салтын сақтаса және үйлесімді тамақтанса энтеротип бірегей және тұрақты жағдайда болады [6]. Қазіргі көзқарас бойынша, барлық адамзат олардағы Bacteroides, Prevotella және Ruminococcus басым болуына қарай шартты түрде үш негізгі энтеротипке бөлінеді [7,8]. Микробиом үш маңызды функцияны қамтамасыз ете отырып: метаболизмдік, қорғаныстық (адам организмінің имунитеті) және алиментарлық (иммундық жүйе функциясын қамтамасыз етуге қатысу, жасушалар дифференциясына және жасушалардың өсуіне ықпал ету), ішек гомеостазын бірқалыпты ұстауда маңызды рөл атқарады.

Алайда, псориаз бен псориаздық артрит кезінде адамның бактериялық микробиомының ерекшеліктеріне акцент жасалған зерттеулер мен шолулар жоқ. Осы себеппен шолу мақаласында микробиомдағы өзгерістер туралы, сондай-ақ псориазбен ауырған пациенттерде ішектің жергілікті иммунитетінің жай-күйі туралы соңғы уақыттағы зерттеулер қысқаша баяндалады.

\section{Псориаз кезіндегі ішек иммунитетінің жай-күйі}

Соңғы онжылдықта асқазан-ішек жолдарын адамның иммундық жүйесінің бір бөлігі ретінде бағалауға мүмкіндік беретін бірқатар зерттеулер жасалды. Гастроинтестиналдық тракт деңгейінде иммундық механизмдерді іске асыруға үш басты компонент қатысады:

- қалыпты микрофлора;

- ішектің сілемейлі қабығының лимфалық тіні;

- цитокиндер - жасушааралық өзара әрекет факторы ретінде;

- иммунокомпетенттік және фагоцит жасушалар секрециясының өнімдері [9].

Псориазбен ауырған пациенттерде ішектің микробиомының өзгерістері туралы жоғарыда айтылды. Ішектің иммундық жүйесінің басқа компоненттеріне көңіл аударайық.

Псориазбен ауырған науқастарда АІЖ лимфалық тінінің жай-күйі туралы мәлімет жоқтың қасы. Аталған проблемаға арналған аздаған мақалалардың бірінде асқазанның сілемейлі қабығы арқауының лимфа тінінің гиперплазиясы және псориазбен ауырған пациенттерде анықталған көптеген лимфа фолликулалары пайда болғаны сипатталған. Алынған мәліметтерді зерттеушілер регенерациялық-арқаулық жеткіліксіздік синдромымен контексте түсіндіреді [10]. Екінші бір зерттеудің авторы мықынішектің сілемейқабықасты қабатында сілемейлі қабық пен лимфалық гранулеманың лимфоплазмоцитарлық инфильтрациясын атап өтті [11].

Ұлтабардың сілемейлі қабығына гистологиялық зерттеу жасағанда мес жасушалар мен эозинофилдердің, сондай-ақ дуоденальдық эпителийішілік лимфоциттер саны көбейгені анықталды. Және де жіңішке ішектің сілемейлі қабығының өз қабатында лимфалық-гистиоциттік инфильтрация бар екені анықталады [12]. Келесі бір зерттеу авторлары шектелген псориазда мес жасушалар саны сондай өзгере қоймайды, ал таралған түрінде олардың гипоплазиясы анықталады деп белгіледі. Сонымен қатар көптеген мес жасушаларда эндоплазмалық кірінділердің дегрануляциясы, «жасырын метахромазия» реакциясының әлсірегені анықталды. Авторлардың пікірінше, мес жасушалардың функциялық әлсірегенінің белгісі деп түсіндіруге болады, бұл әлсіреуді псориаз кезіндегі ішектік дисфункцияның клиникалық белгісі ретінде, ішектің зақымдалуының эндоскопиялық және морфологиялық белгілері, және жуан ішектің микробиомының жай-күйі ретінде анықтауға болады [13].

Осылайша, ішек иммунитетінің жай-күйі іс жүзінде зерттелмеген болып қалып отыр.

Псориаз патогенезінде ішектің тосқауылдық функциясы бұзылуының рөлі

Псориаз бен ішектің тосқауылдық функциясы бұзылуының өзара байланыстылық проблемасы соңғы бірнеше онжылдықтар бойы зерттеушілердің қызу талқылайтын тақырыбы болып жүр. Мысалы, 2000 жылы псориазбен ауырған 45 науқастың мысалында, көмірсулар мен майларға ішек қабырғаларының өткізгіштігінің бұзылатыны анықталды, ол псориаздың ауырлық дәрежесімен және аурудың ұзақтығымен корреляцияланады [14]. Екінші бір зерттеуде кәдуілгі псориазбен ауырған 30 баланы тексеру негізінде аурудың сатысына байланысты гидрофильді макромолекулаларға ішектің өткізгіштігі артқаны анықталды. Және де өткізгіштіктің максималды деңгейі теріде жаңа бөртпелердің пайда болу кезеңімен байланысты болды. Ішектің тосқауылдық функциясының азаюымен иммундық жүйенің активациясы қатар жүрді, қанды зерттегенде DR-позитив моноциттердің және лимфоциттердің саны көбеюінен байқалды [15]. М. Sikora және серіктес авторлар [16] псориазбен ауырған науқастарда жіңішке ішектің сіңіру қабілетінің төмендегенін анықтады, авторлардың пікірінше оған себеп - жіңішке ішектің сілемейлі қабығы құрылымының бұзылуы және ішектің микроорганизмдерінің D-ксилозаны жұтуы. Ю.В. Шагованың деректері бойынша [17] пациенттердің басым бөлігінде псориаз ішек дисфункциясымен қатар жүреді, онда дерматоздың ағымының сипатына қарай әртүрлі морфологиялық субстрат болады: шектелген псориаз пациенттердің 26,7\%-ында тітіркенген ішек синдромымен; науқастардың 20\%-нда созылмалы ойықжаралы емес колитпен қоса жүреді. Аурудың ауырлық деңгейі орташа дәрежелі кең таралған псориазбен 72,9\% жағдайда, ал ауыр дәрежелі псориазда абсолютті жағдайларда созылмалы ойықжаралы емес колит және (немесе) терминалдық илеит қатар жүреді. 
Псориазбен ауыратын науқастарда ішектің сілемейлі қабығының зақымдалуы мен тері процесінің асқынуы арасындағы өзара байланысты басқа авторлар да атап көрсетеді [18,19,20]. Псориазбен ауыратын кейбір науқастарда глиадинге антиденелер анықталған. Глютенсіз емдәмді сақтаған жағдайда олардың 73\%-ында клиникалық белгілердің жақсарғаны байқалды $[21,22]$. Аталған фактілер көптеген мамандарға келесіні дәлелдеуге негіздеме береді: жіңішке ішектің патологиялық өзгерістері - толықтай алғанда, дерматоздың туындауының жиі кездесетін себептері және оның ішінде жекелей алғанда псориаздың жиі кездесетін себебі болып табылады [23].

Ішек колонизациясының табиғи процесі оральдық толеранттылықтың қалыптасу негізінде жатыр - ауыз арқылы түсетін бактерия-комменсалдарға және бактериялық емес антигендерге қатысты жасушалық және гуморалдық иммунитет белсенділігінің физиологиялық азаюында [24]. Аталған процесс бөгде белоктарды қабылдау (тану) мүмкіндігін қамтамасыз етеді. Бактериялық ықпал етуді тануға және қабыну немесе қабынуға қарсы жауапты қалыптастыруда Toll-тәрізді рецепторлар (TLR) маңызды рөл атқарады, олар спецификалық микробтық компоненттерді идентификациялай алады, симбиоздық және патогендік бактерияларды ажырата алады, және ішектің сілемейлі қабығына патогендер енген жағдайда иммундық жауапқа бастама жасай алады [25]. Сонымен қатар олар эпителийлік гомеостаз бірқалыпта ұстауда, эпителийді зақымдалудан қорғауда да және сілемейлі қабықты қалпына келтіруде маңызды рөл атқарады [26].

Осылайша, бірнеше онжылдықтар бойы зерттеушілер тері ауруларының дамуындағы ішектің тосқауылдық функциясы бұзылуының рөлі туралы мәселе талқыланып келеді. Көптеген зерттеулер нәтижесінде псориазбен ауыратын науқастарда ішектің тосқауылдық функциясы бұзылғандығы, оның ішінде сілемейлі қабықтың морфологиялық өзгерістері салдарынан бұзылғандығы анықталды. Сонымен қатар, дерматологиялық патология дамығанда микробиомның бұзылу рөлі туралы мәселе де қызу талқылануда.

\section{Псориаз ауруында ішек микробиомының рөлі}

Түрлі аурулардың, оның ішінде тері патологиясының дамуындағы микробиомның рөлі туралы көптеген зерттеулер псориаз дамуында ішектің микробиомының рөлі туралы тұжырымның дамуына алып келді. Мысалы, M.Sikora мен серіктес авторлардың [27] жұмысында псориазбен ауырған науқастарда ішектік тосқауылдың дисфункциясы микробиота мен иммундық жүйе арасындағы гомеостаздық тепе-теңдікті бұзатыны көрсетілген. D. Richards мен серіктес авторлардың [28] жұмысында псориаз бен ішек микрофлорасы арасындағы өзара байланыс атап көрсетілген, ал L. Galland [29] жарияланымында микробиоценоздың ауысуы - псориазбен ауыратын науқастарда ішектің аса жоғары өткізгіштігінің ықтимал себептерінің бірі деп аталды.

Соңғы жылдары микробиом аурудың клиникаға дейінгі фазасына бірнеше тәсілмен ықпал ететінін дәлелдейтін жаңа деректер алынды, микрофлораның әртүрлілігін және құрамын өзгерту жолымен (дисбиоз|), сондай-ақ иммунологиялық дисрегуляция нысанасы ретінде болды [30,31]. Зерттеудің бірінде псориаздың дамуында микрофлораның рөлін зерттеу кезінде жануар моделінің (ересек тышқандардың) микробиомына антибиотиктерді қолданып, өзгерістер енгізілді, сонымен қатар псориаздық ауруды дамытуға жасанды түрде стимуляция жасалды [32].
Нәтижесінде, псориаз имитацияланған бақылау тобымен салыстырғанда, антибиотиктерді қолданғаннан кейін тышқандардың ішектерінде бактериялар (bacteroidetes, actinobacteria, цианобактерий) құрамы азайды, теріде IL-22 және IL-17 T-өндіретін жасушалар саны азайды. Сонымен қатар, антибиотиктер берілмеген тышқандармен салыстырғанда, ішектен теріге Th17 жасушаларының миграциясына қатысатын Т-жасушалардың беткейіндегі 6 (ccr6) хемокин рецепторы молекулаларының экспрессиясы да төмен болды. Және де неонаталды кезеңінде антибиотик берілген тышқандарда, бақылаумен салыстырғанда, симптомдар айқындау болды және қабыну цитокиндерінің (IL-22 и IL-17) және теріде белсенді Т-лимфоциттердің деңгейі жоғарылады, алайда антибиотик берілген ересек тышқандар тобынан клиникалық картинаның айырмашылығы анықталған жоқ. Авторлар бұл мәселе одан әрі зерттеуді талап етеді деген пікірде. Әйтсе де, олар антибиотик берілген ересек тышқандардың ішектерінде бірқатар микроорганизмдер (Bacteroidetesphylum, s247, lachnospiraceae және Ruminacoccaceae тектестер) мөлшері азайғанын, алайда антибиотик берілген жаңа туған тышқандармен салыстырғанда олардың терісі мен ішектерінде Tenericutesphylum, Lactobacillaceae, және Alcaligenaceа тектестер көбірек болғанын атап өтті. Алынған деректерге сүйеніп, авторлар өмірдің алғашқы кезеңінде бұзылған ішектік микробиом псориаздың дамуына ықпал етуі мүмкін деген ұсыныс жасады. Ішек бактериялары микробиом құрамын, қабыну механизмдерін модульдейтіні және псориазбен ауырғанда аурудың қарқындауына ықпал ететіні анық.

Өз кезегінде, J.U. Scher және серіктес авторлардың [33] жұмысында псориаз бен псориаздық артрит кезіндегі ішек микробиомының құрамы зерттелді және жоғарыда көрсетілгендерден өзгеше деректер алынды. Мысалы, дені сау қатысушылар тобымен салыстырғанда, псориаздық артритпен ауырған пациенттердің ішегінде Ruminococcus, Akkermansia, Pseudobutyrivibrio және Clostridia тектес бактериялар азырақ болды, ал псориазбен ауырған пациенттердің ішегінде Parabacteroides және Coprobacillus бактериялар аз болды. Және де осы екі топ адамдарында ішек микробиомының құрамында айырмашылығы болды. Псориазбен ауырған пациенттермен салыстырғанда, псориаздық артритпен ауырған пациенттерде Akkermansia, Ruminococcus бактериялар сирек кездесті, ал Bacteroidetes және Coprobacillus көп мөлшерде болды. Алайда жоғарыда келтірілген зерттеулер арасындағы бұл айырмашылықтар бұл зерттеулердегі іріктеулердің өлшемдерінің, зерттеу дизайнының (талдамаға арналған бактериялық ДНҚ саласы) сәйкес келмеуінен, қатысушылар құрамына (соңғы зерттеуге псориазбен ауырған пациенттермен қатар псориаздық артритпен ауырған пациенттер де қосылды), пациенттердің әлеуметтік-демографиялық

сипаттамасындағы айырмашылықтарға, сондай-ақ үлгілердің экстракция маусымына байланысты туындауы мүмкін.

J.U. Scher және серіктес авторлар [33] ішектің бактериялық құрамынан басқа, псориаздық артритпен ауыратын пациенттерде қабыну статусы маркерін де зерттеді. Нәтижесінде анықталғаны: оларда секреторлық А (sIgA) иммуноглобулин деңгейі жоғарылаған, ал фекальдық рецептор-активатор каппа- $\beta$ лиганда ядролық фактор (RANKL) деңгейі төмендеген, бұл көрсеткіштер дені сау қатысушылардың көрсеткіштерімен салыстырғанда ғана емес, псориазбен ауырған науқастардың көрсеткіштерімен салыстырғанда да осы нәтижені көрсетті. 
Сонымен қатар, псориазбен ауыратын пациенттердің сарысуында псориазин / s100 деңгейі жоғарылаған (псориаз кезінде шектен тыс айқын), сондай-ақ RANKL ингибиторы болып есептелетін (Liberato M.V. et al., 2012) фекальдық остеопротегериннің де (OPG) деңгейі жоғарылаған. Антибактериялық ықпалдарды көрсететін орташатізбекті май қышқылдарының (MCFAs, Hexanoate және Heptanoate) деңгейі псориазбен ауыратын пациенттерде, оның ішінде псориаздық артритпен ауыратын пациенттерде де төмендеген. Akkermansia мен Ruminococcus бактериялар деңгейі және MCFAs (hexanoate, heptanoate) мөлшері арасындағы оң корреляция анықталды. Akkermansia бактериялардың құрамы фекальдық SIGA және қысқатізбекті май қышқылдары (ацетат, бутират) деңгейлерімен теріс коррелляцияланды. Coprobacillus бактерия құрамы s100 деңгейімен кері коррелляцияланды. Өз кезегінде, фекальдық RANKL деңгейі Lachnosiparaceae бактерияларының құрамымен оң коррелляцияланды, бұл псориаздық артритте төмен болған болатын. Алайда, бір рет өткізілген корреляциялық талдама қорытындысын біржақты түсіндіруге болмайды, себебі бақыланатын ассоциацияға ықпал ете алатын маңызды факторлар назардан тыс қалуы мүмкін.

D. Masallat және серіктес авторлардың [35] жұмысында да псориаз кезіндегі ішек микробиомының ерекшеліктері, оның ішінде бактериялық арақатынас және олардың PASI индексімен байланысы тұрғысынан да талданды. Авторлар зерттеуге қатысқан сау адамдармен салыстырғанда, псориазбен ауыратын науқастарда Firmicutes / Bacteroidetes бактериялар арасындағы арақатынас анағұрлым жоғары екенін анықтады, олардың деңгейі топтар арасында аса ерекшеленбеген болса да. Сонымен қатар, Actinobacteria мөлшерінің көрсеткіші сау топта жоғары болды, бұл кейінірек жасалған Codoner et al. [36], бірақ Scheretal алған нәтижелермен сәйкес келеді [33]. Сонымен бірге, Firmicutes / Bacteroidetes және PASI индексі арақатынастары арасындағы статистикалық расталған оң корреляция анықталды, ал Actinobacteriaphyla мөлшеріне қатысты мұндай корреляция анықталған жоқ. Алайда, зерттеу нәтижесіне келесі факт ықпал етуі мүмкін екенін атап өткен жөн: зерттеуге қатысушылар бір жыл ішінде іріктелген болуы мүмкін, сәйкесінше ішек микробиомының құрамы маусымдарға байланысты өзгеріп отыруы мүмкін. Бұдан басқа, жоғарыда аталған бір де бір зерттеуде пациенттердің иммундық статусына және микробиом құрамына псориазға қарсы терапияның және емдәмнің (вегетариандық, қатаң- вегетариандық, глютенсіз, лактозасыз) ықпалы есепке алынған жоқ.

Кейбір зерттеулерде псориаздың дамуына ішектің қалыпты сапрофиті F. prausnitzii (Firmucutesphylum) рөлі талқылануда. Бұл микроорганизм бутиратты (қысқатізбекті май қышқылдары) өндіреді, ол колоноциттерді энергиямен қамтамасыз етеді, қышқылдану стресінен қорғауға қатысады, қабынуға қарсы әсері бар, Т-эффекторлық жасушалар және регуляторлық Т-жасушаларды реттеуде маңызды рөл атқарады (Tregs) [37,38]. Сонымен қатар, F. prausnitzii митохондриялармен (MAM) байланысқан мембрана белогын өндіреді, ол ішекте белсенді В-жасушалардың (NFкВ) ядролық факторларын басуға қатысады және ішектен тыс жерлерге де белгілі бір ықпалы болуы мүмкін (оның тері иммунитеті реакцияларына қатысуы ықтимал деген сұрақ ерекше қызығушылық тудырып тұр) [39,40].

H. Eppinga және серіктес авторлардың [41] жұмысында псориазбен ауыратын науқастардың, қабынбалы ауруы, іріңді гидрадениті бар науқастардың ішегінде Faecalibacterium prausnitzii және E.coli (Proteobacteriaphylum) құрамы зерттелді. Олар бақылау тобындағы сау адамдарға қарағанда, псориаз топта осы аталған микроорганизм құрамы айтарлықтай төмен екенін байқады, ал басқа эксперименттік топтарда мұндай төмендеу байқалған жоқ.

\section{Қорытынды}

Осылайша, соңғы жылдардағы бірқатар зерттеулерде псориаздың дамуындағы микробиомның рөлі, сондай-ақ ішектің жергілікті иммундық жай-күйі, ішектің тосқауылдық функциясының рөлі көрсетілген. Алайда, зерттеулердің нәтижелері біріне-бірі қарама-қайшы. Бұл топтардың клиникалық тұрғыдан салыстыруға келмейтінімен, әрі жасы-жынысы мен әлеуметтік-демографиялық сипаттарымен де байланысты, сондай-ақ микробиомның маусымдық өзгерістерімен де байланысты. Өз кезегінде, жануарларға жасалған псориазды эксперименттік зерттеу нәтижелерін адамға толықтай экстраполяциялай алмаймыз, оған себеп адам мен жануар миробиомының құрамында айқын айырмашылықтар бар.

Осыған байланысты аталған бағытта зерттеулерді жалғастыру қажет.

Disclosures: There is no conflict of interest for all authors.

\section{Әдебиеттер:}

1. Nestle F.O., Kaplan D.H., Barker J. Psoriasis. Engl. J. Med. 2009; 361(5):496-509. https://doi.org/10.1056/NEJMra0804595

2. Shakirov M.M., Taubaev A.A. Statisnicheskii eshegodnik «Indikatory dermatovenerologicheskoi pomoschi Respubliki Kazahstan. Almaty. 2016; 9

3. Davidovici B.B., Sattar N., Prinz J.C. Psoriasis and systemic infl ammatory diseases: potential mechanistic links between skin disease and co-morbid conditions. J. Invest. Dermatol. 2010; 130:1785-1796. https://doi.org/10.1038/jid.2010.103

4. Kriegel M.A., Self or non-self? The multifaceted role of the microbiota in immune-mediated diseases. ClinImmunol. 2015; 159(2):119-21. https://doi.org/10.1016/j.clim.2015.05.010

5. Gao Z., Tseng C.H, Strober B.E, et al. Substantial alterations of the cutaneous bacterial biota in psoriatic lesions. PLoS One. 2008; 23:3(7):e2719. https://doi.org/10.1371/journal.pone.0002719

6. Gomez A., Luckey D., Taneja V. The gut microbiome in autoimmunity: Sex matters. ClinImmunol. 2015;159(2):154-62. https:// doi.org/10.1016/j.clim.2015.04.016

7. Arumugam M., Raes J., Pelletier E., et al. Enterotypes of the human gut microbiome. Nature. 2011; 473:174-80. https://doi. org/10.1038/nature09944 
8. Koren O., Knights D., Gonzalez A., et al. A guide to enterotypes across the human body: meta-analysis of microbial community structures in human microbiome datasets. PLoSComput Biol. 2013; 9(1):e1002863. https://doi.org/10.1371/journal.pcbi.1002863

9. Duff L.C. Interaction mediating bacterial translocation in the immature intestine. J. Nutr. 2000; 130:432-436. https://doi. org/10.1093/jn/130.2.432S

10. Hardikov S.A., Nepomnyashcih G.I., Aidagulova S.V., Lapii G.A. Ul,trastrukturnaya harakteristika kletochnyx pohulyatsii slizistoi obolochki zheludka i dvenadtsatiperstnoi kishki pri psoriazhe. Byulleten, exsperimenl,noi biologii $i$ meditsiny. 2002; 11:568-573

11. Shagova YU.V. Kliniko-pronostichoe znachenie funktsional,nyh i strukturnyh izmenenii kishechnika pri psoriaze: avtoref. diss. kand. med. nauk. Saratov. 2009; 22.

12. Tolmacheva N.V., Anisimov A.S. Sovremennyi vzglyad na etiologiyu i patogenez psoriaza. Fundamentalnye issledovaniya. 2015; 1(10):2118-2121.

13. Shagov Yu.V., Kozlova I.V. Kliniko-pronostichoe znachenie sostoyaniya slizistoi obolochki kishechnika pri psoriaze. Zdorov,e i obrazovanie XXI veke. 2007; 9 (4):22-24

14. Xardikova S.A., Beloborolova E.I., Pestetev P.N. Psoriaz, kishechnoe vsasyvanie. Tomsk, NTL, 2000; 120.

15. Stenina M.A., Kulagin V.I., Rudkovskaea Sh.V. i dr. Rol, narushenii bar,ernoi funktsii kishechnika v patogeneze psoriaza u detei. Ros.shurn. kosh. $i$ ven.bol. 2003; 2:20-23.

16. Kulikova A.V., Zenin B.A., Uglova M.V.Morfologicheskie izmeneniya slizistoi tonkoi kishki pri psoriaze. Psoriaz: Respublikanskii sbornik nauchnyh rabot. 1989; 18-21.

17. Shagov Yu.V. Kliniko-prognosticheskoe znachenie funktsional,nyh I strukturnyh izmenenii kishechnika pri psoriaze: aftoref.diss. kand.med.nauk. Saratov. 2009; 22.

18. Michaelsson G., Kraaz W., Hagforsen E. et al. Psoriasis patients have highly in-creased numbers of tryptase-positive mast cells in the duodenal stroma. Br. J. Der-matol. 1997; 36 (6):866-870. https://doi.org/10.1046/j.1365-2133.1996.d01-1088_136_6.x

19. Michaelsson G., Kraaz W., Hagforsen E. et al. The skin and the gut in psoriasis: the number of mast cells and CD3 lymphocytes is increased in non-involved skin and correlated to the number of intraepithelial lymphocytes and mast cells in the duode-num. Acta Dermato-Venereol. 1997; 77(5):343-346.

20. Pietzak A., Lecewicz-Torun B., Kadziela-Wypyska G. Changes in the digestive system in patients suffering from psoriasis. Ann. Univ. M. Curie-Sklodowska D. 1998; 53:187-194.

21. Chalmers R. J., Kirby B. Gluten and psoriasis. Br. J. Dermatol. 2000. 142(1):5-7. https://doi.org/10.1046/j.1365-2133.2000.03345.x

22. Michaelsson G., Gerden B., Hagforsen E. et al. Psoriasis patients with antibodies to gliadin can be improved by a gluten-free diet. Br. J. Dermatol. 2000; 142(1):44-51. https://doi.org/10.1046/j.1365-2133.2000.03240.x

23. Khardikova S.A., Beloborodova E.I. Sostoyanie pishevaritelnoi sistemy pri psoriaze. Clinicheskaya medicina. 2012; 2:13-15

24. Spiekermann G., Walker W.A. Oral tolerance and its role in clinical disease. J Pediatr Gastroenterol Nutr. 2001; 32:237-255. https://doi.org/10.1097/00005176-200103000-00003

25. Neish A.S. Microbes in gastrointestinal health and disease. Gastroenterology. 2009; 136:65-80. https://doi.org/10.1053/j. gastro.2008.10.080

26. Rakoff-Nahoum S, Paglino J, Eslami-Varzaneh F et al. Recognition of commensal microflora by toll-like receptors is required for intestinal homeostasis. Cell. 2004; 118:229-241. https://doi.org/10.1016/j.cell.2004.07.002

27. Sikora M., Chrabąszcz M., Maciejewski C. et al. Intestinal barrier integrity in patients with plaque psoriasis. J Dermatol. 2018; 45(12):1468-1470. https://doi.org/10.1111/1346-8138.14647

28. Richards D., Mein E., McMillin D., Nelson C. Systemic aspects of psoriasis: an integrative model based on intestinal etiology. Integrative Medicine. 2000; 2 (2):105-113(9). https://doi.org/10.1016/S1096-2190(00)00010-X

29. Galland L. Power Healing: Use the New Integrated Medicine to Cure Yourself. Random House. 1998:384.

30. Raza K., Gerlag D.M. Preclinical inflammatory rheumatic diseases. Rheum Dis Clin North Am. 2014; 40(4):569-80. https://doi. org/10.1016/j.rdc.2014.07.001

31. Ruff W.E., Kriegel M.A. Autoimmune host-microbiota interactions at barrier sites and beyond. Trends Mol Med. 2015; 21(4):23344. https://doi.org/10.1016/j.molmed.2015.02.006

32. Zanvit P., Konkel J.E., Jiao X. et al. Antibiotics in neonatal life increase murine susceptibility to experimental psoriasis. Nat Commun. 2015; 6:1-10. https://doi.org/10.1038/ncomms9424

33. Scher J.U., Ubeda C., Artacho A. et al. Decreased bacterial diversity characterizes the altered gut microbiota in patients with psoriatic arthritis, resembling dysbiosis in inflammatory bowel disease. Arthritis Rheumatol. 2015; 67:128-39. https://doi. org/10.1002/art.38892

34. Liberato M.V., Nascimento A.S., Ayers S.D. et al. Medium chain fatty acids are selective peroxisome proliferator activated receptor (PPAR) $\gamma$ activators and Pan-PPAR partial agonists. PLoS One. 2012; 7:1-10. https://doi.org/10.1371/journal.pone.0036297

35. Masallat D., Moemen D.F., State A. Gut bacterial microbiota in psoriasis: A case control study. African J Microbiol Res. 2016; 10:1337-43.https://doi.org/10.5897/AJMR2016.8046

36. Codoñer F.M., Ramírez-Bosca A., Climent E. et al. Gut microbial composition in patients with psoriasis. Sci Rep. 2018; 8:1-7. https://doi.org/10.1038/s41598-018-22125-y

37. Atarashi K., Tanoue T., Shima T. et al. Induction of Colonic Regulatory T Cells. Science. 2011; 331:337-42. https://doi.org/10.1126/ science.1198469

38. Qiu X., Zhang M., Yang X. et al. Faecalibacterium prausnitzii upregulates regulatory T cells and anti-inflammatory cytokines in treating TNBS-induced colitis. J Crohn's Colitis. 2013; 7:e558-68. https://doi.org/10.1016/j.crohns.2013.04.002 
39. Khan M.T., Van Dijl J.M., Harmsen H.J.M. Antioxidants keep the potentially probiotic but highly oxygen-sensitive human gut bacterium Faecalibacterium prausnitzii alive at ambient air. PLoS One. 2014; 9:212-214. https://doi.org/10.1371/journal. pone.0096097

40. Quévrain E., Maubert M.A., Michon C. et al. Identification of an anti-inflammatory protein from Faecalibacterium prausnitzii, a commensal bacterium deficient in Crohn's disease. Gut. 2016; 65:415-25.

41. Eppinga H., Sperna Weiland C.J., Thio H.B. et al. Similar depletion of protective Fae-calibacterium prausnitzii in psoriasis and inflammatory bowel disease, but not in hidradenitis suppurativa. J Crohn's Colitis. 2016; 10:1067-75. https://doi.org/10.1093/ ecco-jcc/jjw070

How to cite this article: Togzhan Algazina, Bakytgul Yermekbayeva, Almagul Kushugulova, Samat Kozhakhmetov, Zulfiya Jetpisbayeva, Gulnar Batpenova. The role of intestinal barrier function and the state of the intestinal microbiome in psoriasis [in Kazakh]. J Clin Med Kaz. 2019; 2(52):10-15 